\title{
CHPT1 wt Allele
}

National Cancer Institute

\section{Source}

National Cancer Institute. CHPT1 wt Allele. NCI Thesaurus. Code C104911.

Human CHPT 1 wild-type allele is located within $12 \mathrm{q}$ and is approximately $47 \mathrm{~kb}$ in length.

This allele, which encodes cholinephosphotransferase 1 protein, is involved in phosphatidylcholine metabolism. 